\title{
An Assessment of Microfinance in Socio-economic and Psychological Empowerment of Women in Some Selected Western Zones of Oromia Region
}

\author{
DUGASA RAFISA OLANA \\ Lecturer, Accounting And Finance, Wollega University, Nekemte, Ethiopia
}

\begin{abstract}
As a matter of course, the position of women in Ethiopia has been low compared to men. Women are poorer, have low education and suffer from traditions and customary laws. This study explores the position of micro finances in socio-economic and psychological empowerment of women. The study is causal type of research to clearly depict the relation (correlation) between empowerment of women and microfinance institution. Since the study uses survey method the research approach is basically quantitative. Qualitative data have been used in support. Convenient sampling strategy were in work to select study sites as the research is proposed to be done in four selected zones of Western Oromia region. From the total population of 2559 female customers having relation with MFIs and engaged in various business activities in the western part of Oromia region, the researcher selected 334 persons as a sample respondent based on Simple random sampling technique on Proportional base. Primary data is the main source of data and the data were obtained by using questionnaire and interview. To analyze the data inferential statistics like t-test were applied to gain an insight about the change before and after the microfinance intervention in women's life. Linear regression and correlation analysis are also made with the help of statistical package for social science (SPSS version 20). It is found that Women are economically, socially and psychologically empowered by participating or dealing with microfinance program. Focus on providing Skill trainings, consultancy and consciousness raising training which are supposed to be combined with the core function of a microfinance program of providing financial services let women's give power to themselves or feel empowered .
\end{abstract}

Keywords: Microfinance, economic, social and Psychological empowerment

DOI: $10.7176 /$ RJFA/10-17-01

Publication date:September $30^{\text {th }} 2019$

\section{INTRODUCTION}

Even though Ethiopia is on a dramatic change in a political and economic development after a power handover of Dr. Abiy Ahmed as a prime minister one year before; yet today, Ethiopia remains one of the world's poorest countries. Of a population exceeding 90 million people, 78 percent live on less than $\$ 2$ per day. Ethiopia's struggle with poverty and slow development is inextricably tied to its history of conflict, recurrent drought, and environmental degradation. This situation is further complicated by deep traditional social and economic patterns that place powerful constraints on the rights of women and their opportunities to direct their own lives or participate in and contribute to community and national development (Wilder, 2007).

Women in Ethiopia lack opportunity in the formal sector compared to men. This is likely because men have long dominated management and other leadership positions, which are more available in the formal sector, and because the informal sector offers more flexibility for women who must also take care of household duties. Due to the time burden effect that causes women to divide their time between their jobs in the labor market and their duties at home and due to lingering beliefs among corporate leaders that men are the financial providers of the family, women across Kenyan and Ethiopia receive less pay than men, even in the same jobs (Cannon, 2010).

According to Central Statistics Authority (1996) there are more women (64.3\%) than men in the informal sector. Despite their contribution to the economy and social development, however, they did not enjoy the fruits of development equally as their male counterpart. To this effect, they do not have access to, health, education, and other productive resources and they are not adequately represented in leadership and decision making positions at all level (Prime Minister Office/Women's Affairs Sub Sector, 2004).

Women empowerment is a process in which women challenge the existing norms and culture, to effectively improve their well-being. Malik (2005) describes empowerment as "the enhancement of assets and capabilities of diverse individuals and groups to engage, influence and hold accountable the institutions which affect them". Malik further says among the different disempowered groups like: poor, ethnic, minorities etc., women are one which is cross-cutting category with all these groups. Similarly, women empowerment implies that women have power and ability to do activities as like men counterpart but they have the least authority to do something at their own initiation. It necessitates the endorsement of various national Programs and policies which ensures their right and authority to involve in all the developmental as well as economic activities carried out in a society, or in a nation. 
The emergence of women entrepreneurs and their contribution to the national economy is quite visible and undisputable. Yet the fact is that women in almost all the known societies of the world, past or present, have not enjoyed the same status, privileges, rights and powers as that of men. Knowing that the empowerment of women breeds many positive special effects for society as a whole makes the task of shaping the underlying factors of women's empowerment essential (Basnet,2006).

Women's movements in a number of countries identified credit as a major constraint on women's ability to earn an income and became increasingly interested in the degree to which poverty-focused credit programs and credit cooperatives were actually being used by women. Investing in women's capabilities empowers them to make choices, which will contribute to greater economic \& social growth and development. Microfinance programs have to be increasingly promoted for their positive economic impact and the belief that they empower women. Access to savings and credit can initiate or strengthen a series of interlinked and mutually reinforcing 'virtuous spirals' of empowerment by providing access to loans for income-generating activities, microfinance institutions can significantly increase a woman's resources, thereby reducing her overall vulnerability. Furthermore, it is well-documented that women are more likely than men to spend their income on household and family needs. Assistance to women has therefore been shown to generate a multiplier effect that improves the welfare of the whole family (Gobezie, 2010).

The main aim of microfinance is to empower women. Women make up a large proportion of microfinance beneficiaries. Traditionally, women (especially those in underdeveloped countries) have been unable to readily participate in economic activity. Microfinance provides women with the financial backing they need to start business ventures and actively participate in the economy. It gives them confidence, improves their status and makes them more active in decision-making, thus encouraging gender equality (S. Sarumathi, 2011).

\section{RELATED REVIEW LITERATURE}

Microfinance programs in the recent past have become one of the more promising ways to use scarce development funds to achieve the objectives of poverty alleviation. Microfinance institutions around the world have been quite creative in developing products and services that avoid barriers that have traditionally kept women from accessing formal financial services such as collateral requirements, male or salaried guarantor requirements, documentation requirements, cultural barriers, limited mobility, and literacy. Nevertheless, in a number of countries and areas few or no institutions offer financial services under terms and conditions that are favorable to women (Susy Cheston).

\section{Concept of Empowerment}

All the development efforts would be only half done if there is no effective participation of females (Arjun Kumar Thapa, 2010). Empowerment is conceptualized as an emancipation process in which the disadvantaged are empowered to exercise their rights, obtain access to resources and participate actively in the process of shaping society and making decisions. A focus on empowerment emphasizes that poverty not only is about low incomes, but also emanates from social exclusion and the lack of access to power, voice and security (Cecilia Luttrell, 2009). Empowerment is a multi- dimensional social process that helps people to gain control over their own lives, communities and in their society, by acting on issues that they define as important (Medatwal, 2013). It is the process of acquiring the ability to make strategic life choices in a context where this ability has previously been denied (Arjun Kumar Thapa, 2010).

World Bank (2001) defines women empowerment as the process of increasing the capacity of individuals to make choices and transform those choices into desired actions and outcomes. Again in its empowerment sourcebook, 'empowerment is the expansion of assets and capabilities of poor people to participate in, negotiate with, influence, control, and hold accountable institutions that affect their lives. Having this meaning Medatwal (2013) asserts empowerment is a multi- dimensional social process that helps people to gain control over their own lives, communities and in their society, by acting on issues that they define as important and Microfinance is the current buzzword in alleviating the problems of the community. Empowerment refers the expansion of freedom of choice and action to shape one's life. The economic, social and political are often critical in ensuring that women are empowered, when women's individual or collective ability to recognize and utilize resources in their own interests (Malhotra, 2003). No society can develop sustainably without increasing and transforming the distribution of opportunities, resources, and choices for males and females so that they have equal power to shape their own lives and contribute to their communities (USAID, March 2012).

\section{Economic empowerment}

Economic empowerment has been defined in several ways by various researchers and organizations. In simple terms, economic empowerment combines the concepts of empowerment and economic advancement. Approaches to economic empowerment on factors that help women succeed and advance in the marketplace. This includes increasing skills and access to productive resources, improving the enabling and institutional 
environments, and assisting women in their ability to make and act upon decisions in order to benefit from economic growth and development. Economic empowerment is intertwined with social and political empowerment (Department of Foreign Affairs, 2013). Women are more likely than men to engage in lowproductivity activities. They are also more likely to be in wage or unpaid family employment or work in the informal wage sector. However, as women gain employment and education, women's bargaining power in the home and workplace is likely to improve (UK Department for International Development, 2013).

The majority of women contribute more to their households due to receiving microcredit (Helge Roxin, 2010). Women's access to savings and credit gives them a greater economic role in decision- making through their decision about savings and credit. When women control decisions regarding credit and savings, they will optimize their own and the household's welfare. The investment in women's economic activities will improve employment opportunities for women and thus have a 'trickle down and out' effect (Prakash, 2006).

Economic empowerment seeks to ensure that people have the appropriate skills, capabilities and resources and access to secure and sustainable incomes and livelihoods. Related to this, some organizations focus heavily on the importance of access to assets and resources (Cecilia Luttrell,2009). In addition to economic empowerment Cecilia Luttrel explained human and social empowerment as a multidimensional social process that helps people gain control over their own lives. This is a process that fosters power (that is, the capacity to implement) in people, for use in their own lives, their communities and their society, by being able to act on issues that they define as important.

\section{Social Empowerment}

Microfinance provides women with the financial banking they need to start business ventures and actively participate in the economy. It gives them confidence, improves their status and makes them more active in decision-making, thus encouraging gender equality (Gundappa, 2014). A combination of women's increased economic activity and control over income resulting from access to micro-finance with improved women's skills, mobility, access to knowledge and support networks. Status within the community is also enhanced. These changes are reinforced by group formation, leading to wider movements for social and political change (Prakash, 2006).

Several studies identified social benefits that women gain from participating in microfinance programs. They feel less marginalized, have higher aspiration for their children's education and future, use more reliable source of drinking water, are more likely to use latrines and contraceptives, and are less likely to marry at an early age (Webster, 1996).

A combination of women's increased economic activity and control over income resulting from access to microfinance with improved women's skills, mobility, and access to knowledge and support networks. Status within the community is also enhanced. These changes are reinforced by group formation, leading to wider movements for social and political change (Amankwaa, 2012).

\section{Psychological empowerment}

Empowerment of women means to let women survive and let them live a life with dignity, humanity, respect, self-esteem and self-reliance. Thomas (1990) have resulted in psychological empowerment being defined in narrow terms as the motivational concept of self-efficacy and in broad terms as increased intrinsic task motivation. Microcredit can support internal psychological empowerment processes among clients. There are certain indicators of Self-perception such as self-confidence and self-esteem, which shed light on this (Helge Roxin, 2010).

The participation of women in business enables them to acquire inimitable psychological benefits to rise up psychologically powerful which are an essential for women empowerment in any socio- cultural and economic environment and situations. The members have accrued various psychological benefits including self-awareness, high self-esteem, and self-confidence and courage, understanding about own rights, privileges, roles \& responsibilities, power of self- determination, positive attitude, risk taking ability, the power to face challenges of daily life, gaining knowledge and new ideas and skills, great relief from mental stress and anxiety, leading a happy and satisfied life and so on (G. Valarmathi, 2014).

\section{Role of microfinance in empowering women}

The microfinance institutions can promote the entrepreneurial capabilities of self-help groups in several ways like marketing, training etc. Microfinance programs envisage several other changes along with the income generating activities among the women members. An enquiry into the impact of microfinance on the members of microfinance reveal that a number of qualitative changes have been brought into their life. Mobility, increased role in family decision making, gain family respect, attending public meetings, deal with officials, banking habit were the major perceived changes among the female members of microfinance (Medatwal, 2013). Women are the key actors in the microfinance system and the core function of a microfinance program is to 
provide financial services, to reach poor women and men and give them access to savings and credit (Kulkarni, 2011). Microfinance programs have significant potential for contributing to women's economic, social and political empowerment. women's movements in a number of countries identified credit as a major constraint on women's ability to earn an income and became increasingly interested in the degree to which poverty-focused credit program and credit cooperatives were actually being used by women. Access to savings and credit can initiate or strengthen a series of interlinked and mutually reinforcing 'virtuous spirals' of empowerment. Microfinance development has emerged as major strategy to combat the twin issues of poverty and unemployment that continue to pose a major threat to the polity and economy of both the developed and developing countries (Prakash, 2006). Microfinance services lead to women empowerment by positively influencing women's decision making power at household level and their overall socioeconomic status. Microfinance plays a great role in the lives of millions of poor people particularly women. Most areas of city, where microfinance loan is disbursed, dearth of women decision making at domestic level exist in both rural and urban areas of city (Noreen, 2011).

Microfinance has come to play a major role in many gender and development strategies because of its direct relationship to both poverty alleviation and to the empowerment of women (Gobezie,2010). Microcredit has a strong positive impact on income changes for the majority of clients given that there is sufficient market demand and that clients invest well in their businesses. Transferring these income gains into greater material security and reduced vulnerability. Microcredit has a strong potential to reduce poverty within the majority of clients' households. It also have a positive influence on livelihood stabilization by enabling increased expenditure on strategic needs (Helge Roxin, 2010). Microfinance is a powerful tool to self-empower the poor people especially women at world level and especially in developing countries (Ashok K., 2014).

A study conducted by Amankwaa Samuel (2012) women were able to increase their income and provided not only with the financial help to their families but also had positive impact on other factors of daily life. These women brought about a positive change to their financial and social situation and started taking active part in the decision making process of the family and society.

\section{Why women empowerment}

Women constitute more than $50 \%$ of the population, undertake most of the work (two thirds) but only receive one tenth of the total income rather than men. The working hours of women are longer than that of men, 1216 hours per day. In addition to their domestic responsibilities in child care, women have to be responsible for housework, such as fetching firewood, water \& cooking \& even hard work as sloughing \& raking, planting, transplanting \& harvesting. Women have to suffer from continuing under nutrition $\&$ two thirds of them are anemic. They have lower status \& low paid occupations, lower economic positions so they are less conscious \& lack self- confidence (G.Valarmathi, 2014). Economically empowering women is essential both to realize women's rights and to achieve broader development goals such as economic growth, poverty reduction, health, education and welfare. Empowering women is a win-win that can benefit not only women, but society more broadly. It promotes women's ability to achieve their rights and well-being while also reducing household poverty, increasing economic growth and productivity, and increasing efficiency.

\section{Critical review of related empirical literature}

Many of the studies conducted in line with MFIs have mainly emphasized assessing the impacts of micro finance programs on poverty reduction. Most of them were mixed as in comparative between rural and urban areas; men and women; clients and non-clients. Others have focused on the roles of micro finance programs on the alleviation of unemployment owing to the persistence of the problems across the country (Befikadu,2011). Besides the above study there is a research conducted by Mohammed (2006) focuses on the role of microfinance in strengthening pastoral household food security in Liban zone of Somali region centering in only food security. However, there is one study conducted in Arbaminch concerning women empowerment through micro finance by Befikadu, 2011. Nevertheless, he need to discover or achieve in his objectives the components of MFI, Investigate factors affecting women participation in MFP in the study area, Examine women perception and experiences of empowerment through MFP. In the research he done is mostly trying to identify the challenges women are facing \& their perception towards empowerment. However, in this study am trying to identify how their (women) life's really changed by using MFI services just like their ability of decision making, mobility, control over saving, owning asset/property and their self-confidence \& self- efficacy rather than finding out the challenges they are facing when dealing with MFI.

\section{MATERIALS AND METHODOLOGY}

\section{Research design}

The study is causal type of research to clearly depict the relation (correlation) between empowerment of women and microcredit institution. It basically employed survey method based on cross-sectional data. The choice of the 
survey method is motivated by the fact that it best describes the opinions, personal characteristics, perceptions, preferences and attitudes of respondents. The choice of a survey method is further informed by the fact that the survey method enables a wider coverage area whiles giving respondents the opportunity to analyze their individual contributions and identify different barriers existing among the various population sub-groups (Hair, 1998). Besides, the survey method is deemed appropriate since it enables one gather data on relatively large number of people at the same time, and can be done using structured questionnaires. The research approach is basically quantitative in support with qualitative data.

\section{Measurement}

The aim of this research is basically to study the role microfinance played in changing women's life economically, socially and psychologically. In this research, the items measured based on Likert scale type of questionnaires. To realize changes happens in women's' life as of their participation in microfinance or microcredit programs the member's socio-economic status and psychological state have been compared before and after usage of microfinance programs.

\section{Sampling method and sample size}

In the study Simple random sampling method have been employed which involves assembling a sample in such a way that each independent, same-size subset within a population is given an equal chance of becoming a subject. As it is free from human bias and classification and being highly representative of a population it simplifies data interpretation and analysis of results. Convenient sampling strategy was in work to select study sites as the research is conducted in four selected zones of Western Oromia region. The selection of the study sites are based on infrastructure, accessibility and the time and effort required to execute the study in accordance with the plan. Simple random sampling let individuals to be included as representative of the population from which it is selected. The number of sample elements drawn from each sites were based on Proportion. Trends within the sample act as excellent indicators of trends in the overall population to determine the relevant sample size so us to enable to conclude about the population accurately.

\section{Sample size determination}

In case of finite population the following formula were used to select the appropriate sample size based on $95 \%$ confidence level and 5\% margin of error or level of precision.

Where,

$$
\mathrm{n}=\frac{\mathrm{z} 2 \times \mathrm{p} \times \mathrm{q} \times \mathrm{N}}{\mathrm{e} 2(\mathrm{~N}-1)+\mathrm{z} 2 \times \mathrm{p} \times \mathrm{q}}
$$

$\mathrm{p}=$ sample proportion, $\mathrm{q}=1-\mathrm{p}$

$\mathrm{z}=$ the value of the standard variate at a given confidence level and to be worked out from table showing area under Normal Curve;

$\mathrm{n}=$ size of sample.

Source: C.R. Kothari (2004)

Given: At $95 \%$ confidence level the value of $\mathrm{Z}=1.96 \mathrm{P}=$ the population proportion (assumed to be .50 since this would provide the maximum sample size).

$\mathrm{N}=2559$ which is population size $\quad \mathrm{e}=0.05$ which is acceptable sample error

$$
\begin{aligned}
& \mathrm{n}=\frac{(1.96) 2 \times 0.5 \times 0.5 \times 2559}{\mathrm{n}=334} \\
& \mathrm{n}=33 \mathrm{n}(2559-1)+(1.96) 2 \times 0.5 \times 0.5
\end{aligned}
$$

From the total population of 2559 female customers having relation with MFIs and engaged in various business activities in Somali region the researcher have selected 334 individuals as sample respondent. 
Study sites and respective number of total population and sample size

\begin{tabular}{|l|l|l|}
\hline Study sites & Total No population in Study sites & Sample size on proportion \\
\hline East Wollega & 948 & 123 \\
\hline West Wollega & 537 & 70 \\
\hline Qelem Wollega & 567 & 74 \\
\hline Horo G/Wollega & $507 \quad \mathbf{2 5 5 9}$ & 67 \\
\hline \multicolumn{2}{|c|}{ Total } & $\mathbf{3 3 4}$ \\
\hline
\end{tabular}

Source: Microfinance office of each zonal office 2018/19

NB: the proportion have taken based on the following formula.

$\mathrm{P}=\frac{\mathrm{X} n}{\mathrm{~N}} \quad$ Where: $\mathrm{P}$ is population proportion

$\begin{array}{ll}\mathrm{X} & \text { is the number of elements in the site population } \\ \mathrm{N} & \text { is population size } \\ \mathrm{n} & \text { is sample size }\end{array}$

\section{Data Source}

The sources of data for this research paper were women involved in various activities having relation with microfinance/micro credit institutions. This group will be suitable for the study since it will afford the researcher to assess the contribution of microfinance to women empowerment socially, economically and psychologically. Hence, the data source basically a primary source.

\section{Data Collection Method}

The study basically is a survey research; hence the researcher mainly relied on primary data. The questionnaires have been distributed to women beneficiaries of microfinance program in the selected zones of western oromia region. Besides, data were gathered through interviews from some selected clients of microfinance.

\section{Data Manipulation Method}

The collected data from randomly selected customers were summarized by using Excel and transferred to SPSS and analyzed. The output obtained from the software has been presented using tables. Mean scale as a measure of central tendency were used to show where the majority of responses concentrate i.e. nearer to which scale the representative middle value of responses is found. As a statistical tool, the Difference-Sample $t$-test (paired sample t-test) have been used which allows to test whether a two sample means, collected from the same group on two separate occasions, are significantly different from each other. T-test is in work to make a comparison in women's socio-economic status and their psychological state of situation before and after participating in microfinance programs and to clearly portray the changes that comes in women's life in subsequent usage of the program. The linear regression have been used to determine the amount of variance accounted (the change in one variable (independent variable) in predicting the dependent variable) additionally spearman correlation analysis placed functional on that data to find out the association of the variables.

\section{Model specification}

Women socio-economic and psychological empowerment $(\mathrm{Y})=\mathrm{B} 0+\mathrm{B} 1 \mathrm{X} 1+\mathrm{E}$

Where, $\mathrm{X} 1=$ Microfinance service and

Products

$$
\begin{aligned}
& \mathrm{B} 1=\text { Regression Coefficients } \\
& \mathrm{B} 0=\text { Regression Constant. } \\
& \mathrm{E}=\text { the residual error, which is an unmeasured variable }
\end{aligned}
$$

\section{RESULTS AND DISCUSSION}

Results

The data collected from the female customer of microfinance institution using questionnaires are presented and analyzed in this chapter. The dimension of women empowerment analyzed using Mean value and mean difference and presented in tables. Finally, discussions are made based on the data presented and analyzed.

The data were collected through survey questionnaire. Out of the 334 questionnaires distributed to the randomly selected women respondents 311 are properly completed and returned. This represents a response rate of $93 \%$ from the distributed questionnaires. Hence, data gathered were organized and analyzed in a manner that enables to answer the basic research questions raised at the beginning of the study and test hypothesis. Responses provided by the respondents are analyzed in the following sections. 
Descriptive statistics of Microfinance services

\begin{tabular}{|l|l|c|}
\hline S.No. & \multicolumn{1}{|c|}{ Items } & Mean Value \\
\hline 1. & The credit provided by MFI really helpful & 4.203 \\
\hline 2. & $\begin{array}{l}\text { The ability of generating income provides me a confidence and think of increasing the } \\
\text { business }\end{array}$ & 4.244 \\
\hline 3. & $\begin{array}{l}\text { The microcredit helps to generate income and contribute for the family and social } \\
\text { organization }\end{array}$ & 3.968 \\
\hline 4. & $\begin{array}{l}\text { The MFI put an effort to provide people with access to a range of financial products } \\
\text { and services }\end{array}$ & 3.762 \\
\hline & \multicolumn{1}{|c|}{ Overall mean } & 4.045 \\
\hline
\end{tabular}

Source: own survey

Access to credit is upheld to have a potential contribution on improved resource base among women borrowers. Evidence from the table reveals that micro credit provision can potentially enhance the ability of generating income and provides a confidence as well as think of increasing the business. The microcredit helps women's contribute for the family and social organization. Over all the microcredit coupled with range financial services was really helpful and in their life which is reflected with the overall mean of 4.045 nearer to agreement. Women's access to savings and credit enables them to start their own economic activities, acquire assets or raise their status in household economic activities through their visible capital contribution which in turn bring changes in their social interaction and psychological state of condition.

Descriptive Statistics of Economic empowerment of women

\begin{tabular}{|c|c|c|c|c|}
\hline \multicolumn{5}{|c|}{ Economic empowerment of women } \\
\hline & \multirow[b]{2}{*}{ Items } & \multicolumn{2}{|c|}{ Mean Value } & \multirow[b]{2}{*}{$\begin{array}{c}\text { Mean } \\
\text { Difference }\end{array}$} \\
\hline S.No & & $\begin{array}{l}\text { After } \\
\text { Microfinance } \\
\text { intervention }\end{array}$ & $\begin{array}{l}\text { Prior to } \\
\text { Microfinance } \\
\text { intervention }\end{array}$ & \\
\hline 1. & $\begin{array}{l}\text { Ability to increase and control } \\
\text { incomes and resources }\end{array}$ & 4.203 & 1.611 & 2.592 \\
\hline 2. & Ability in contributing family support & 4.627 & 1.187 & 3.44 \\
\hline 3. & $\begin{array}{l}\text { Authority to decide regarding what is } \\
\text { being done with savings and credit in the } \\
\text { household }\end{array}$ & 4.476 & 2.293 & 2.183 \\
\hline 4. & $\begin{array}{l}\text { Registration of property and assets in } \\
\text { your own name }\end{array}$ & 2.412 & 2.228 & 0.184 \\
\hline 5. & Overall mean & 3.93 & 1.83 & 2.1 \\
\hline
\end{tabular}

Source:own survey

The preceding table indicates that the cumulative (overall) mean and mean difference for the women economic empowerment and each constituents that would help to measure economic empowerment. After served by microfinance the overall mean of women economic situation has shown the mean value of 3.93 and prior to microfinance intervention the mean value was 1.83 . The mean scores in the table above shows the economic dimensions where significant change has taken place regarding women contribution to the family and their ability of increasing and control of incomes and resources. However, the right of entitlement of property and assets has shown minimal change compared with other changes. This may count a number of reasons as it is outlined by a number respondents their partners are playing significant role putting all the assets and property in their own name. Land and owning of home are the most valuable assets and property they do consider. Other factors contribute for women deprival of property entitlement accounts the customarily laws which inherit assets to their counterparts (male). In addition, women face many obstacles to claiming their property rights and low level of awareness of their rights, the time and expense of pursuing claims, and the social stigma of being considered greedy or traitors to culture if they assert their rights. 
Descriptive Statistics of women on social empowerment

\begin{tabular}{|c|c|c|c|c|}
\hline \multicolumn{5}{|c|}{ Social condition } \\
\hline & \multirow[b]{3}{*}{ Items } & \multicolumn{2}{|c|}{ Mean Value } & \multirow[b]{3}{*}{$\begin{array}{c}\text { Mean } \\
\text { Difference }\end{array}$} \\
\hline & & After & Prior to & \\
\hline S.No & & $\begin{array}{l}\text { Microfinance } \\
\text { intervention }\end{array}$ & $\begin{array}{l}\text { Microfinance } \\
\text { intervention }\end{array}$ & \\
\hline 1. & Freedom and confidence of movement & 4.20 & 2.12 & 2.08 \\
\hline 2. & $\begin{array}{l}\text { Ability to raise voice against social } \\
\text { exploitation }\end{array}$ & 2.77 & 2.64 & 0.13 \\
\hline 3. & Acceptance \& respect from the society & 4.62 & 2.17 & 2.45 \\
\hline 4. & Getting help of other family members & 4.28 & 2.33 & 1.95 \\
\hline 5. & Overall mean & 3.97 & 2.32 & 1.65 \\
\hline
\end{tabular}

Source: own survey

The above table indicates the alteration of women's social interaction within their family and their social consciousness in the community after taking part in microfinance programs actively. After the microfinance involvement the women have shown great improvement fostering their social interaction and were rated at high level (3.97). This implies that the social image of women's in the eye of the relatives and society were changed. Since women are generally considered as not active as of men in the public sphere due to social constraints in the past. Maximum number of respondents accepted that microfinance has brought Freedom and confidence of movement, Ability to raise voice against social exploitation though it is minimal compared with others, Acceptance \& respect from the society and getting help of other family members and happiness and peace in the family. The mean difference score identifies the microfinance contribution in the women's social dealings and interaction before and after shown how much change (improvement) has been attained with the value of 1.65. Descriptive Statistics of Psychological Condition

\begin{tabular}{|c|c|c|c|}
\hline \multicolumn{4}{|c|}{ Psychological Condition } \\
\hline \multirow[b]{3}{*}{ Items } & \multicolumn{2}{|c|}{ Mean Value } & \multirow[b]{3}{*}{ Mean Difference } \\
\hline & After & Prior to & \\
\hline & $\begin{array}{l}\text { Microfinance } \\
\text { intervention }\end{array}$ & $\begin{array}{l}\text { Microfinance } \\
\text { intervention }\end{array}$ & \\
\hline have Self-esteem/confidence on my own & 4.20 & 1.79 & 2.41 \\
\hline Have Self-efficacy and value for myself & 4.48 & 2.09 & 2.39 \\
\hline $\begin{array}{l}\text { Aspired and motivated to articulate } \\
\text { strategies for change }\end{array}$ & 4.63 & 2.81 & 1.82 \\
\hline Shown improvement in courage & 4.20 & 2.11 & 2.09 \\
\hline Overall mean & 4.38 & 2.20 & 2.18 \\
\hline
\end{tabular}

Source:own survey

As far as the Psychological improvement was concerned, the table above Indicate that Psychological improvement of women as a result of the intervention of microfinance in women's life rated was the largest mean observed in the study, which are 4.38. This means members have accrued various psychological benefits including self-awareness, high self-esteem, Have Self-efficacy, self- confidence, courage, aspired, motivated and ready for change and articulate strategies to take opportunities. Involvement in microfinance offers helps clients to improve their self-esteem.

\section{Regression analysis}

Regression analysis is used to analyze and understand how the value of a dependent variable, in our case women empowerment is influenced by changing the value of an independent variable when others are held constant. A regression model for predicting women empowerment was developed with microfinance as predictor of women empowerment. The coefficients are used to represent the mean changes in the response variable for one unit of change in the predictor variable while holding other predictors in the model constant. 
The overall model summary women Empowerment (Economic, Social \& Psychology)

Model Summaryb Women Empowerment

\begin{tabular}{|c|c|c|c|c|c|c|c|c|c|}
\hline \multirow{2}{*}{ lodel } & \multirow[t]{2}{*}{$\mathrm{R}$} & \multirow{2}{*}{$\begin{array}{c}\mathrm{R} \\
\text { Square }\end{array}$} & \multirow{2}{*}{$\begin{array}{l}\text { Adjusted } \\
\text { R Square }\end{array}$} & \multirow{2}{*}{$\begin{array}{l}\text { Std. Error } \\
\text { of the } \\
\text { Estimate }\end{array}$} & \multicolumn{5}{|c|}{ Change Statistics } \\
\hline & & & & & $\begin{array}{l}\mathrm{R} \mathrm{Sq} \\
\mathrm{Cha}\end{array}$ & $\begin{array}{c}\mathrm{F} \\
\text { Change }\end{array}$ & df1 & $\mathrm{df} 2$ & $\begin{array}{c}\text { Sig. F } \\
\text { Change }\end{array}$ \\
\hline - & .751 & .564 & .563 & .33975 & .564 & 400.022 & 1 & 309 & \\
\hline
\end{tabular}

a. Predictors: (Constant),

Microfinance

b. Dependent Variable: Women Empowerment

The coefficient of determination R2 was compared to determine percentage variation in the dependent variable. The above table clearly shows the value of $\mathrm{R}, \mathrm{R} 2$, adjusted $\mathrm{R}$ square and other results. In this analysis the value of $\mathrm{R}$ is $0.751 \mathrm{a}$ which is a measure of the correlation between the observed value and the predicted value of dependent variable of women socio-economic and Psychological empowerment of women. The Correlation Coefficient was computed for the purposes of determining whether a statistically significant relationship exists between the microfinance service and products and women empowerment (Economic, Social and Psychological). The results indicate that there was a direct and strong relationship between microfinance products and service and women empowerment. The Correlation is significant at the 0.01 level (2-tailed).

Whereas, R Square (R2) as the percentage of variance in dependent variable (women socio- economic, and Psychological empowerment) that can be explained by independent variable (microfinance services and products). Hence, R2 $=0.564$ implies that $56.4 \%$ of the variance in women socio-economic, and Psychological empowerment can be explained by the microfinance services and products. R square is subject to optimistic overestimation of the true value in the population. Adjusted $\mathrm{R}$ square corrects this value to provide better estimate of the true population value. So, the prediction ability of the model is expressed by adjusted $\mathrm{R}$ square which is 56.3 percent of the variance in women socio-economic and Psychological empowerment.

\section{Regression coefficients}

Respective Regression coefficient of Economic, Social, Psychological empowerment

\begin{tabular}{|c|c|c|c|c|c|c|c|}
\hline \multicolumn{8}{|c|}{ Coefficient } \\
\hline Model & \multicolumn{2}{|c|}{$\begin{array}{l}\text { Unstandardized } \\
\text { Coefficients }\end{array}$} & $\begin{array}{l}\text { Standardized } \\
\text { Coefficients }\end{array}$ & $\mathrm{t}$ & Sig. & Collinearity & istics \\
\hline & B & Std. Error & Beta & & & Tolerance & VIF \\
\hline (Constant) & 1.966 & .121 & & 16.185 & .000 & & \\
\hline Microfinance & 0.485 & .030 & .682 & 16.394 & .000 & 1.000 & 1.000 \\
\hline
\end{tabular}

\begin{tabular}{|ll|r|r|r|r|r|} 
& & & & & & \\
1 & (Constant) & .110 & .135 & 15.625 & .000 & \\
0.460 & .033 & .622 & 13.975 & .000 & 1.000 & 1.000 \\
& Microfinance & & &
\end{tabular}
$\left|\begin{array}{ll}1 & \text { (Constant) } \\ & \text { Microfinance }\end{array}\right|$
1.468
.719
$.123 \mid$
\begin{tabular}{r|r|} 
& 11.933 \\
$.807 \mid$ & 24.003
\end{tabular}
.000
.000
1.000
1.000

a. Dependent Variable: Psychological empowerment

In predicting the women empowerment in three dimension, it is found that microfinance has made bigger contribution in explaining the dependent variable of psychological empowerment $(0.807, t=24.003)$ followed by economic empowerment $(\beta=0.682, \mathrm{t}=16.394)$, and social empowerment $(\beta=0.622, \mathrm{t}=13.975)$. The one unit increment on explanatory variable will bring 80.7 percent change for psychological empowerment, 68.2 percent in economic empowerment and 62.2 percent of change on women social empowerment. All the change is significant which is asserted by $\mathrm{P}$ value (level of significance) of $0.001(\mathrm{P}<0.05)$. 
The overall Regression coefficients women empowerment

\begin{tabular}{|c|c|c|c|c|c|c|c|c|c|c|}
\hline & & & & efficien & & & & & & \\
\hline \multirow{2}{*}{ Model } & \multicolumn{2}{|c|}{$\begin{array}{l}\text { Unstandardized } \\
\text { Coefficients }\end{array}$} & \multirow{2}{*}{ 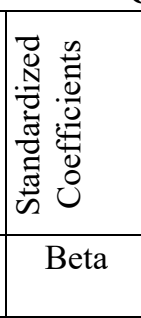 } & \multirow[t]{2}{*}{$\mathrm{t}$} & \multirow[t]{2}{*}{ Sig. } & \multicolumn{3}{|c|}{ Correlations } & \multicolumn{2}{|c|}{$\begin{array}{l}\text { Collinearity } \\
\text { Statistics }\end{array}$} \\
\hline & B & $\begin{array}{l}\text { Std. } \\
\text { Error }\end{array}$ & & & & $\begin{array}{l}\begin{array}{l}\text { Zero- } \\
\text { order }\end{array} \\
\end{array}$ & Partial & Part & 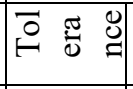 & VIF \\
\hline \multirow{2}{*}{\begin{tabular}{|ll} 
& (Constant) \\
1 & Microfinance \\
\end{tabular}} & 1.848 & .114 & & 16.232 & .000 & & & & & \\
\hline & .555 & .028 & .751 & 20.001 & .000 & .751 & .751 & .751 & 1.000 & 1.000 \\
\hline
\end{tabular}

a. Dependent Variable: Women Empowerment

The regression beta value measures how strongly the predictor variable influences the criterion variable. The t-value and significance level assess the extent to which the magnitude of the change in dependent variable has been attained. The regression coefficient represent the mean change in the response variable for one unit of change in the predictor variable while holding other prediction in the model constant.

The beta is measured in units of standard deviation which is for every one unit increase in the predictor variable the dependent variable (women socio-economic, and Psychological empowerment) will have shown change of 0.555 standard deviation. To construct equation un standardized beta were used, which indicates contribution of each of independent variable in explaining the dependent variable. The beta value (rate of change) of regression coefficient with a level of significance equal to 0.001 signposts the microfinances in the region of Somali has significant contribution to women socio-economic and Psychological empowerment. The t-value and significance level assess the extent to which the magnitude of the change in dependent variable has been attained with the significance level of $\mathrm{p}<0.05$.

\section{Discussion of findings}

This paper tried to analyze the role of MFI in socio economic and psychological empowerment of women. In Ethiopia 80 percent of the population resides in rural areas and women provide the majority of the agriculture labor in these communities. However, women's access to resources and community participation are usually mediated through men, either their fathers or husbands, and their agricultural contributions often go largely unrecognized. Additionally, when women have access to their own income, they are more likely than men to spend it on the betterment of their families and successfully participate in the village savings or pay school fees for their children (USAID, 2016).

Traditionally, women (especially those in underdeveloped countries) have been unable to readily participate in economic activity. Microfinance provides women with the financial backing they need to start business and actively participate in the economy. It gives them confidence, improves their status and makes them more active in decision-making, thus encouraging gender equality. Giving women access to microcredit loans therefore generates a multiplier effect that increases the impact of a microfinance institution's activities, benefiting multiple generations (S.Sarumathi, 2011).

Investing in women has proven to increase the positive impact of microfinance programs since women are more likely than men to spend their income on household and family needs (Gobezie,

2010). More than one-third of currently married employed women who earn cash make independent decisions about how to spend their earnings (CSA, 2011). Women often face different and more basic economic constraints than men, linked to a lack of access to credit and lower demand for their products because of marketing inexperience. To support women's ability to create businesses and secure their own livelihoods, better in encouraging the financing of female-owned businesses through the Development Credit Authority (USAID, 2016). Studies show that women's access to microcredit empowers them in various ways, the same studies and many others also reveal that in the context of women's empowerment, it is safe to say that "loan alone moans" (Ashok K., 2014).

The writer explains the prediction ability and the contribution of microfinance program to women economic, social and psychological empowerment. According to the study finding Microfinance plays a foremost role in women development strategies. Channeling credits through women may enable them to generate and control incomes and resources. It has direct relationships with improvement of livelihood of women's (economic empowerment). It lets them play an active role in intra household decision making, decrease potential household vulnerability and increase investment in family welfare. Women spend most of their income on their family needs particularly children's education and nutrition, health care and clothing. According to Clinton Global Initiative (2016) When women work, they invest 90 percent of their income back in to their families. The study made by Noreen (2011) purports, Microfinance is a powerful tool to self-empower the poor people especially 
women at world level and especially in developing countries. It has been well documented that an increase in women resources or better approach for credit facilities results in increased wellbeing of the family especially children (Mayoux L., 1997; Kabeer, 2001). Hunt and Kasynathan (2002) describes that microfinance programs for women have positive impact on economic growth by improving women income generating activities.

On their study Sultana and Hasan (2010) found out that women who had access to microcredit experienced income rise and able to save more money as compared to their counterparts. Another significant outcome revealed by the study was increase in the women's ownership of assets as result of accessibility to credits because they could afford such assets through profits generated from their microenterprises. Ownership of valuable assets, such as a house or land, provides multiple avenues for empowerment. These assets may serve as a place to live or earn a livelihood, as collateral for loans or investments to expand economic or social opportunity, and as a safety net against crises. Lack of assets is associated with greater poverty and economic vulnerability (Sara K. Head, 2014).

The findings of regarding economic empowerment asserted by Mayoux (2000) extensively advocates that women's access to savings and credit creates economic empowerment associated with choices they make concerning credit and savings. It enables them to start their own economic activities, invest more in existing activities, acquire assets and raise their status in household economic activities through their visible capital contribution.

The findings of Helge Roxin (2010) suggest that microcredit has a substantial impact on women's economic empowerment. Taking women's access to credit observed several positive changes on a material level, such as business expansion, higher income and increases in expenditure on immediate and strategic needs. Most women in this association (microfinance) experienced increased income and therefore improved their economic status, political and social conditions after receiving the loans (Amankwaa S., 2012).

Furthermore, it is well documented that women have fewer resources available to them, they tend to be more vulnerable when economic challenges or unforeseen circumstances arise. By providing access to loans for income-generating activities, microfinance institutions can significantly increase a woman's resources, thereby reducing her overall vulnerability (Gobezie, 2010). Ebisa Deribe (2013) asserts this study signifying the role of microfinance institutions are decisive way outs from the vicious circle of poverty particularly for the rural and urban poor segment of the society especially in a country like Ethiopia where many people live barely below the absolute poverty line.

The findings of a study articulates microfinance intervention have brought women socially empowered which is reflected through their freedom and confidence of movement within the community and find it easy to visit their family and neighbors and make them stood beside them. Microcredit is thought to empower women in household decision making processes. Adding it gives them a freedom to interact effectively in the public sphere and generate acceptance $\&$ respect from the society, Participation in non-family groups and discuss on various agendas of customary laws and social exploitation.

The findings associated social condition of women Hashemi (1996) confirms that credit programs provide access to an important economic resource, and consequently enable women to bargain gender barriers, increase their control over their own lives, and improve their relative positions in their households. Credit programs increase the role of women in household decision making and it increases social networks and having greater freedom of mobility (Pitt, 2003). Microcredit services lead to women empowerment by positively influencing women's decision making power at household level and their overall socioeconomic status. Some of these changes include increased participation in decision making, more equitable status of women in the family and community (Noreen, 2011). Savings and loans program creates significant and positive changes in the incidence of intimate partner violence, attitudes towards violence against women, in household decision- making and negotiation (International Rescue Committee). Microfinance intervention Improves women bargaining power within existing relationships (Oriana Bandiera, 2015).

\section{CONCLUSION AND RECOMMENDATION}

\section{Conclusion}

In developing nations women's are highly marginalized and subject to various discriminating social and cultural factors which ends up economically dependent and psychologically distressed. They have to cross those sociocultural, economic and the mental and emotional state of complications when they want to work for money. Their identity is lost under the burden of responsibilities. Answer to all these difficulties lies in the frame work of women's empowerment. Women's empowerment is a multidimensional process that involves transforming those various complicated socio-cultural, economic and the emotional factors through resource and power allocation and let them play the role bringing on the stage. Nations cannot achieve their development goals if their women are discriminated. A woman who has access to savings, credit and other financial services is more resilient and better able to deal with everyday demands. Microfinance helps poor and low-income clients deal with their basic needs. 
The goal of this research is to study the role of microfinance Institutions on the economic, social and psychological empowerment of women. The results obtained from the analysis reveals that microfinance schemes are highly associated with economic, social and psychological empowerment. Most of the women who had taken credit from the microfinance institution was able to increase their income and provided big financial support to help their families but also these women not only brought about a positive change to their financial stands but also enabled to take active part in the decision making process of the family regarding what is being done with savings and credit in the household. Nevertheless, the analysis of the data obtained in this study indicates that women clients realized meagre change in accessing of property and assets in their own name. This may count a number of reasons as it is outlined by a number respondents their partners or families are playing significant role putting all the assets and property in their own name. Land and owning of home are the most valuable assets and property they do consider. Other factors contribute for women deprival of property entitlement accounts the customarily laws which inherit assets to their counterparts (male). In addition, women face many obstacles to claiming their property rights and low level of awareness of their rights, the time and expense of pursuing claims, and the social stigma of being considered greedy or traitors to culture if they assert their rights.

Furthermore, highly significant association was found between microfinance and women social empowerment. Microfinance allows women's greater involvement in social activities which lets them to generate acceptance $\&$ respect from the society. In addition it help them to exchange views and attain supportive atmosphere from family members that enhance their empowerment. The intervention of microfinance allows them to create social networking, raised social consciousness and participate in social activities, increased tendency of sharing of their problems with their circle of friends and which finally lets them generate acceptance $\&$ respect from the society. Women have shown improvements to raise voice against social exploitation but it is minimal change as compared to others.

From the study, we have come to the conclusions that there is a noticeable and positive impact of microfinance activities on the psychological empowerment of women. Microfinance enhances women ability in developing Self-esteem/confidence, Self-efficacy and value for themselves and aspired and motivated to articulate strategies for change. The study has shown that access to financial services has improved the status of women within the family and the community. Women have become more assertive and confident.

A highly significant positive and direct correlation is found between the criterion variable indicating that Improvement in one criterion variable leads to a positive change in the other criterion variable. The interdependency level of criterion variable is high and the change in one dimension paves the way for change of other criterion variable.

\section{Recommendation}

To bring socially, economically, politically and economically empowered women, the government should strengthen social bonds among women and enhancing social skills and collective advocacy. Allow and work on women (saving and credit groups) to develop shared concerns that translate into social action that reflect common interests. Focus on social cohesion among group members, encourage social organization among women.

MFI need to increase their accessibility and extend their services to cover women in the remotest parts to offer easy access and they should also ensure effective monitoring and supervision.

\section{References}

AMANKWAA SAMUEL, A.-A. S. (2012). EMPOWERMENT OF RURAL WOMEN: THE ROLE OF MICROFINANCE INSTITUTIONS. Unpublished, 1-90.

Aregawi, T. (2003). THE IMPACT OF MICROFINANCE THE IMPACT OF MICROFINANCE ON POOR WOMEN . Unpublished Thesis.

Arjun Kumar Thapa, L. G. (2010). AN ASSESSMENT OF FACTORS INFLUENCING EMPOWERMENT LEVEL OF FEMALES. Economic Journal of Development.

Ashok K., P. R. (2014). ROLE OF MICRO-FINANCE IN THE EMPOWERMENT OF THE WOMEN. Journal of Business and Finance, 21-31.

Basnet, S. R. (2006). Do income generating Programmes Empower Women? A discussion on the changing status of women in rural Nepal.

Bhusal, M. K. (2010). DOES MICROFINANCE REALLY EMPOWER? A study on the contribution of microfinance in empowering the poor women of northern Bangladesh. Unpublished thesis, 24.

Cannon, A. (2010, aapril 07). Life of One's Own: Women's: Women's Education and Economic Empowerment in Kenya.

Caren Grown, G. R. (2003). Achieving Gender Equality and the Empowerment of Women. Washington D.C.: International Center for Research on Women. 
Cecilia Luttrell, S. Q. (2009). Understanding and operationalising empowerment. London: Overseas Development Institute.

CHF, I. (2012). Ethiopia Needs Assessment Report Somali Region - Gode \& Warder Zones.

CLINTON GLOBAL INITIATIVE. (2016, June 25). Empowering Girls and Women. Retrieved from CLINTON GLOBAL INITIATIVE: ClintonGlobalInitiative.org

Cronbach, L. (1998). Coefficient alpha and the internal structure of tests. Psychometrika.

CSA. (2011). Ethiopia Demographic and Health Survey. Addis Ababa, Ethiopia: Central Statistical Agency.

Department of Foreign Affairs, T. a. (2013). Women's Economic Empowerment: Guidance Note. 1.

Ebisa Deribie, G. N. (2013). Filling the breach: Microfinance. Journal of Business and Economic Management, 1(1), 14.

European Parliament. (2016, February). Women's empowerment and its links to sustainable development. Brussels: Policy Department C: Citizens' Rights and Constitutional Affairs European Parliament. Retrieved from http://www.europarl.europa.eu/studies

EZZEDDINE MOSBAH, M. B. (2013). Micro Finance Institutions' behavior: Determinants of portfolio quality in MENA region . Recent Advances on Finance Science and Management,68-71.

Fund, U. N. (2005). www.unfpa.org. Retrieved October 12, 2013, from www.unfpa.org/swp/2005> G. Valarmathi, J. J. (2014). A STUDY ON PSYCHOLOGICAL EMPOWERMENT OF WOMEN IN URAPAKKAM, KANCHEEPURAM DISTRICT. EPRA International Journal of Economic and Business Review, 81-84.

G. Valarmathi, J. J. (2014). A STUDY ON PSYCHOLOGICAL EMPOWERMENT OF WOMEN IN URAPAKKAM, KANCHEEPURAM DISTRICT. EPRA International Journal of Economic and Business Review, 82-84.

Gobezie, G. (2010). Empowerment of Women in Rural Ethiopia. Journal of Human Security, XXV,24.

Gundappa, M. (2014). MICRO FINANCE AND EMPOWERMENT OF WOMEN: AN IMPACT STUDY OF SHGS. Indian Streams Research Journal, 4(8), 1-6.

Hair, A. T. (1998). Multivariate data analysis (5th ed.). New Jersey: Prentice-Hall.

Hashemi, S. S. (1996). Rural Credit Programs and Women's Empowerment in Bangladesh. WorldDevelopment.

Helge Roxin, H. B. (2010). Economic Empowerment of Women through Microcredit. Berlin/ Germany: Humboldt Universität zu Berlin.

Hunt J, K. N. (2002). Reflections on microfinance and women's empowerment. Development Bulletin, 71-75.

International Labor Organization. (1998). Women in Informal Sector and Their Access to Microfinance. Inter- Parliamentary Union Annual Conference. Windhoek, Namibia. International Labour Organization. (nd). Small change, Big changes: Women and Microfinance. International Rescue Committee . (nd). Getting down to business: Women's economic and social empowerment in Burundi. New York: International Rescue Committee .

Kabeer, N. (2001). Reflections on the Measurement of Women's Empowerment: In Discussing

Women's Empowerment Theory and Practice. Novum Grafiska . Kabeer, N. (2004). Empowerment of Women Through Microcredit - working paper Plenary Session

Financing Microfin ance for Poverty Reduction. Microcredit summit . Dhaka, Bangladesh.

Kasynathan, H. (2002). Reflections on microfinance and women's empowerment. Development Bulletin, 71-75.

Kulkarni, V. (2011). Women's empowerment and microfinance. Women's empowerment and microfinance (pp. 24-32). Asia and the Pacific Division.

Malhotra, A. (2003). CONCEPTUALIZING AND MEASURING WOMEN'S EMPOWERMENT AS A VARIABLE IN INTERNATIONAL DEVELOPMENT. Measuring Empowerment: Cross-Disciplinary Perspectives (p. 5). Washington DC: World Bank.

Malik, N. H. (2005). Impact of Micro Credit on women empowerment. 3-4.

Mayoux. (2000). Micro-finance and the empowerment of women: A review of the key issues. Mayoux, L. (1997). The Magic Ingredient? Microfinance and Women's Empowerment, A Brief Paper prepared for the Micro Credit Summit. Washington: A Brief Paper prepared for the Micro Credit Summit.

Medatwal, C. (2013). Role of Microfinance in Empowerment of Women. Pacific Business Review International, 27.

MOHAMMED, N. A. (2006). THE ROLE OF MICROFINANCE IN STRENGTHENING PASTORAL HOUSEHOLD FOOD SECURITY .

Narayan, D. (2002). EMPOWERMENT AND POVERTY REDUCTION. Washington DC: World Bank.

Noreen, S. (2011). ROLE OF MICROFINANCE IN EMPOWERMENT OF FEMALE POPULATION OF BAHAWALPUR DISTRICT. International Conference on Economics and Finance Research (pp. 318-319). Singapore: IACSIT Press.

Oladipo, S. (2009). PSYCHOLOGICAL EMPOWERMENT AND DEVELOPMENT . Edo Journal of 
Counselling, 119-126.

Oriana Bandiera, N. B. (2015). Women's Empowerment in Action: Evidence from a Randomized Control Trial in Africa. Unpublished, 22.

Pitt, M. K. (2003). Credit Programs for the Poor and the Health Status of Children in Rural Bangladesh. International Economic Review.

Prakash, J. (2006). Microfinance and Women Empowerment: An Empirical Study with special reference to West Bengal. Prime Minister Office/Women's Affairs Sub Sector . (2004). A National Report on Progress made in the Implementation of the Beijing Platform for Action. Addis Ababa, Ethiopia.

S.Sarumathi, K. (2011). ROLE OF MICRO FINANCE IN WOMEN'S EMPOWERMENT. Journal of Management and Science, 1-10.

Sara K. Head, S. Z. (2014). WOMEN'S LIVES AND CHALLENGES: Equality and Empowerment since 2000. Rockville, Maryland, USA: United States Agency for International Development.

Sen, A. (2000). Development as Freedom. New Delhi: Oxford University Press. Studies, E. S. (2008). Gender Inequality and Women's Empowerment. Addis Ababa.

Sultana S, H. S. (2010). Impact of Micro-Credit on Economic Empowerment of Rural Women. A Scientific Journal of Krishi Foundation.

Susy Cheston, L. K. (nd). Empowering Women Through Microfinance. UNIFEM.

SWAIN, R. B. (2007). Can Microfinance Empower Women? Self-Help Groups in India. 75-76. Thomas, K. W. (1990). Cognitive elements of empowerment: An interpretive model of intrinsic task motivation. Academy of Management Review, 666-681.

UK Department for International Development, I. r. (2013). WOMEN'S ECONOMIC EMPOWERMENT, GENDER EQUALITY AND GROWTH IN LOW INCOME COUNTRIES. UK, Canada.

UN Economic and Social Council, Commission on the Status of Women . (2012, 27 February - 9 March ). PSYCHOLOGICAL PERSPECTIVES ON THE EMPOWERMENT OF RURAL WOMEN AND GIRLS AS A STRATEGY FOR ERADICATING POVERTY. Women 2000: gender equality, development and peace for the twenty-first century: Implementation of strategic objectives and action in critical areas of concern, and further actions and initiatives, pp. 1-12.

UNIFEM. (2002). PROGRESS OF THE WORLD'S WOMEN: GENDER EQUALITY AND THE MILLENNIUM DEVELOPMENT GOALS.

United Nation Education, S. a. (May 2011- May 2012). Global Partnership for Girls' and Women's Education. UNESCO.

USAID. (2016). Gender Equality and Women's Empowerment. USAID. Retrieved June 2016, from http://www.usaid.gov/ethiopia USAID. (March 2012). GENDER EQUALITY AND FEMALEEMPOWERMENT POLICY.

WASHINGTON, DC: U.S.Agency for International Development. Retrieved from www.usaid.gov

Webster, L. P. (1996). The Informal sector and Microfinance Institutions in West Africa. World Bank Regional and Sectoral.

Wilder, J. (2007). Women's Empowerment in Ethiopia: New Solutions to Ancient Problems. Pathfinder International.

Wilder, J. (2007). Women's Empowerment in Ethiopia: New Solutions to Ancient Problems. Addis 